УДК 347.73

DOI https://doi.org/10.32849/2663-5313/2020.4.35

Свген Маринчак,

канд. юрид.наук

\title{
ПОНЯТТЯ ТА ПРАВОВА ПРИРОДА ПОДАТКОВОГО СУВЕРЕНІТЕТУ
}

Стаття присвячена науковій проблематииі кониепиї податкового суверенітету держави. У статті досліджуються погляди науковиів на політичний суверенітет, робиться ретроспективний аналіз наукових позииій на ию правову категорію. Звертається увага, що суспільство організовується у форму держави за певними особливими характеристиками, шо ідентифікують його з-поміж інших спільнот та навколо певних ідеалів. Сдиним джерелом влади в сучасній правовій державі є народ населення иієї держави, що здійснює владу безпосередньо і через органи державної влади та органи місиевого самоврядування. Суверенітет держави - ие верховенство публічної влади у формуванні та реалізаиї внутрішньої та зовнішньої політики на всій територї, на яку поширюється така влада. За наслідком дослідження суверенітету держави в статті робиться висновок про різні види суверенітету сучасної держави. Наукові позииї на внутрішню будову суверенітету держави в частині відтворювальних майнових процесів відображають таку класифікачію: державний суверенітет економічний суверенітет - фінансовий суверенітет - фіскальний суверенітет - податковий суверенітет. Також розглядається змістовий складник иієї категорії. Фінансова система держави грунтується не на надходженнях до публічних фондів коштів від реалізаиї сировини або наданні дозволів на здійснення певної діяльності з метою отримання прибутку, а на оподаткуванні - всі державні інститути забезпечуються фінансовими ресурсами переважн з податкових надходжень. Таким чином, податковий суверенітет - ие одна з головних ознак сучасної держави. Надається визначення правовій категорії «податковий суверенітет» - ие визнане міжнародним співтовариством виключне право держави на породження податкових правовідносин на своїй територї, що поширюються на осіб, які пов'язані з державою фінансово-правовим зв'язком. Розглядаються наукові позииї шодо виключного права держави на запровадження податкових правовідносин. Аналізуються види та рівні поширення податкової юрисдикиї держави. Пропонуються уніфіковані підходи до законодавчого визначення правового статусу осіб, що забезпечують головну функиію фінансових правовідносин - мобілізацію грошових коштів до державного бюджету України.

Ключові слова: публічні фінанси, податковий суверенітет, податкова юрисдикція, фінансовоправовий зв'язок, публічна влада.

Постановка проблеми. Актуальність цієї статті полягає в тому, що з інтеграцією світової економіки та розвитком міжнародної співпраці в реалізації податкової політики концепція податкового суверенітету потребує законодавчого закріплення. Своєю чергою майбутні правові норми мають бути належно науково обгрунтовані.

Аналіз останніх досліджень і публікацій. Сучасну проблематику суверенітету держави досліджували такі науковці, як: В.Д. Гапотій, О.Я. Коваль, І.М. Коваль, А.С. Романова, І.Д. Софінська, Н.В. Ткаченко та інші. Питання взаємозв'язку осіб 3 державою 3 приводу мобілізації коштів до публічних фондів на науковому рівні також розглядали представники доктрини фінансового права, такі як Г.С. Андрущенко, Л.К. Воронова, Д.О. Білінський, Д.О. Гетманцев, О.В. Гедзюк, Н.Л. Губерська, С.Т. Кадькаленко, М.П. Кучерявенко, Н.М. Ковалко, Р.М. Лещенко, О.А. Лукашев,
С.О. Ніщимна, Н.Ю. Пришва, Л.М. Чуприна, Н.Я. Якимчук та інші.

Не вирішені раніше проблеми. Натепер в українському науковому просторі відсутні комплексні дослідження правової категорії «податковий суверенітет». Зокрема, потребує дослідження генезис та розвиток цієї категорії, іï внутрішня будова та змістовий складник.

Метою статті $є$ подальший розвиток наукових положень про податковий суверенітет.

Виклад основного матеріалу. Проаналізувавши відносини, що відбувались у первісному суспільстві, в часи, коли не існувало держав, можна побачити, що виключними правами над напрямами вирішення своїх нагальних потреб було наділене суспільство, що спільно проживало на одній території. Рішення в таких громадах приймалися на загальних зборах. Громада так чи інакше мала сусідню громаду, 3 якою існували 
конфлікти, в тому числі через природні ресурси. Як зазначає науковець М.Я. Сюзюмов: «у принципі кожне плем'я перебувало в стані війни 3 кожним іншим плем'ям, 3 яким воно не уклало мирну угоду» [1]. У разі укладення мирної угоди природні ресурси і відповідно територія розподілялись. З'являлися кордони. Приблизно так і створювались перші протодержави.

Найвища форма політичної організації суспільства називається державою, у вузькому значенні - це апарат управління та примусу, тобто публічна влада. Варто звернути увагу, що держава - це не об'єкт матеріального світу, а публічна інституція, що існуе в суспільній свідомості. Публічна влада в перших державах належала одній особі, воля якої відображала волю всієї громади. На загальних зборах громада схвалювала важливі рішення керівника держави. Але на певному історичному етапі змінилась концепція наділення керівника виключним правом на управління державою, за новою концепцією верховним правом керівник був наділений богом. У зв'язку з чим відбулися такі зміни невідомо, можливо, через легітимізацію спадкування монаршого титулу. 3 плином часу суверенітет монарха, як верховної влади над його підданими, було замінено концепцією суверенітету держави.

Суверенітет держави - це верховенство публічної влади у формуванні та реалізації внутрішньої та зовнішньої політики на всій території, на яку поширюється така влада. Суверенітет є невід'ємним атрибутом держави. Відповідь на питання про суб'єкта, що наділив публічну владу верховним правом, залежить від поглядів на походження держави. За теологічною теорією верховним правом на регулювання суспільних відносин на певній частині території публічну владу наділено богом; за аксіологічною теорією природна самоорганізація суспільства призвела до створення стійкого об'єднання людей, які були пов'язані спільними культурними цінностями.

У наукових джерелах можна побачити, що вперше термін «суверенітет» застосував французький філософ і юрист Жан Боден (Jean Bodin). Його вчення було викликане необхідністю подолання феодальної роздробленості європейських держав, усунення церковного повновладдя та гегемонії Священної Римської імперії. Верховна влада в державі в цю пору асоціюється перш за все з монархом, влада якого освячена богом та який фактично є власником держави. 3 часом у науковій літературі поступово змінюється акцент у розумінні суверенітету - від теократичного до аксіологічного
[2]. Це пов'язане з тим, що за наслідком реформаційних змін, що відбулись в Європі у XVI ст., церква втратила свої позиції у державному управлінні. В епоху Відродження наукова спільнота активно обгрунтовувала природні права людини. В цей час відбувається відокремлення здійснення публічної влади від власності на державу. Верховна влада починає асоціюватися не з конкретною особою, а з абстрактним за своїм характером інститутом - державою. Важливим етапом у розвитку теорії суверенітету є поява концепції народного суверенітету. Її поява була неминучою, оскільки після того, як подолали виправдання існування верховної влади в суспільстві виключно волею божою, з'явилась необхідність у новій її легітимації. Нове джерело суверенної влади було знайдено у вигляді народу [2]. Німецький філософ Георг Вільгельм Фрідріх Гегель (Georg Wilhelm Friedrich Hegel), досліджуючи правову категорію «суверенітет», виходив з того, що держава є монопольним суб'єктом права. За переконаннями філософа, сучасну правову трансформацію державного суверенітету зазвичай іменують «обмеженням прав суверенітету» або «відмовою від частини суверенних прав». Якщо «старий» суверенітет був насамперед довільним домаганням на правову монополію й абсолютне право за принципом «права сильного», то суверенітет нового типу постає як особливий правовий обов’язок щодо безлічі інших суб’єктів права. Перехід від старої концепції суверенітету до нової означає перехід від довільного насильства до правової санкції, від силової боротьби до правопорядку [3].

Легітимізацію влади доречно окреслити як процес набуття уповноваженості державою, іï апаратом та посадовими особами через їх схвалення народом унаслідок безпосереднього або опосередкованого легального вибору. Здійснивши синтез понять «легальність» та «раціональна легітимність», О.Я. Коваль визначає правову категорію «легітимність влади» як: здійснення влади державою, державним апаратом, посадовими особами, уповноваженими на це народом у встановлених ним нормативно-правових межах. Таким чином, легітимність стає наслідком легітимації, або інакше кажучи, процесу переходу народного суверенітету в нову формальну якість - стан суверенітету державного [4]. На переконання I.M. Коваля, публічна влада має грунтуватись на базових для суспільства цінностях. Стосовно цього науковець зазначає, що національна ідея потрібна суспільству й особливо державі. Держава має знати, чого вона хоче, яке суспільство потрібно будувати, у якому 
напрямі розвиватися. Для цього існують вектори розвитку, напрями у вигляді національно-правових ідей. Звичайно, суспільнодержавні ідеї випливають із сенсу життя

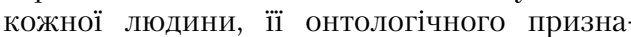
чення. Тобто щоб держава набувала онтологічного статусу, вона має підтримувати онтологічний статус кожної людини, враховуючи індивідуальні та групові особливості. Національне право має грунтуватися на сформованому правовому світогляді суспільства, нації та національній ідеї, яку підтримує держава Тобто право має відповідати духу суспільства, бути своїм, мати визнані впродовж віків власні дозволи і заборони. При цьому завдяки правовому світогляду національне право узгоджується з міжнародним правом, оскільки жити в ізольованому суспільстві, закритій державі стає дедалі складніше [5].

Вищенаведена наукова позиція є правильною, адже суспільство організується у форму держави за певними особливими характеристиками, що ідентифікують його 3-поміж інших спільнот та навколо певних спільних ідеалів. Узагальнивши наукові позиції, номінальне визначення дефініції «суверенітет держави» можна надати таким чином: це виключне право держави з формування внутрішньої та зовнішньої політики, яке обмежується лише суверенними правами інших держав. Формування реальної дефініції залежить від наукової площини дослідження цієї правової категорії.

Носієм суверенітету і єдиним джерелом влади в сучасній правовій державі є народ населення цієї держави, що здійснює владу безпосередньо i через органи державної влади та органи місцевого самоврядування. 3 цього прослідковується прямий та безпосередній політико-правовий зв'язок між фізичними особами та державою. Держава це особлива політико-правова форма організації суспільства, що створена з метою забезпечення належного рівня його існування та розвитку через функціонування відповідних соціальних інституцій. Іншими словами, першоджерелом та найвищою владою (сувереном) на території держави $є$ її населення. 3 огляду на вищенаведене, варто звернути увагу на рівні поширення суверенітету держави. Науковець В.О. Гідірим наводить досить актуальну класифікацію: особистий суверенітет - це верховенство держави над особами, що безпосередньо пов'язані 3 державою (юридичні та фізичні особи), що складається з права поширення законів або їх застосування на осіб, де б вони не перебували, тобто юридичний зв'язок триває, навіть коли особи залишають територію держави; територіальний суверенітет передбачає вер- ховенство державної влади над усіма особами та матеріальними благами, що знаходяться в межах її території; функціональний суверенітет - зв'язок особи з державою, коли остання не володіє повноцінним державним суверенітетом, проте здійснює обмежений, відносно нове явище, результат діяльності держав на морському шельфі і розвитку морського права, а також роботи міжнародних організацій [6].

Держава визначає статус, становище людини в суспільстві, фіксує особливості її існування. Це становище таке, що людина не може існувати поза державою, поза певною культурою. Однак держава також немислима без людини, бо будь-яка держава - це, по суті, колектив людей (безліч індивідів), і дії держави - це дії людини, наділеної певним статусом від імені всіх або більшості [3]. В античній Греції людина - це насамперед вільний громадянин полісу, який за власною волею, свідомо та ініціативно сплачує податки у формі фінансування тих або інших публічних потреб. А тому у більшості містдержав Древньої Греції винятково платники податків мали право голосу та могли бути вибраними у будь-які органи публічної влади полісу. В містах-державах античної Греції існувала правова доктрина громадянства, де у контексті антропологічної реальності під громадянством розумівся насамперед статус кожної людини, ефективний спосіб містадержави відокремлювати своїх громадян від інших та визначати приналежність людей до конкретних міст-держав. Громадянин містдержав античної Греції був активним і безпосереднім учасником «творення державної волі», а також посередньо, вибираючи державних урядовців [7]. Тобто з самого початку заснування інституту громадянства в нього було закладені політичні права та публічні обов'язки для громадян. Крім того, через інститут громадянства можна простежити дієвий спосіб легітимізації публічної влади, сутність якого полягає в тому, що якщо особа набула статусу громадянина, то вона визнала державу та її публічну владу.

Науковець І.Д. Софінська зазначає, що з часом відбувся певний перегляд античних доктринальних положень громадянства, наявних у містах-державах Греції та у Римській імперії, концепція громадянства та її аксіологічні характеристики змінювалися та модифікувалися. У часи Середньовіччя громадянство проявлялося зазвичай у двох формах: як патронаж з боку монарха або як асоційоване членство. Згодом економічне відродження та створення «вільних міст» вчинили серйозний вплив на еволюцію парадигми громадянства. Концепція громадянства поступово 
змінювалася і модифікувалася під впливом філософсько-правових та політико-правових думок мислителів XVII-XX століть, відбулося певне переосмислення іiі основних ознак. Укорінення сучасного розуміння концепції громадянства відбулося саме під час Французької революції 1789-1799 років, а «свідоцтвом про народження» громадянства є Декларація прав людини та громадянина 1789 року [7]. Великі соціально-політичні перетворення в Європі наприкінці XVIII століття заклали фундамент у сучасну концепцію громадянства. Варто звернути увагу, що нова концепція громадянства, як і в Античні часи, передбачає прямий взаємозв'язок громадянина $з$ державою - публічною надбудовою організованого суспільства, а не з владою, яка з волі божої керує цим суспільством. Іншими словами, громадяни мають обов'язки перед державою, а не перед монархом, своєю чергою основні права існують не через те, що їх дарував монарх, а у зв'язку з їх природним буттям.

Здійснивши ретроспективний аналіз, І.Д. Софінська доходить висновку, що протягом XX століття розвиток концепції громадянства та іï аксіологічних характеристик відбувся в основному на підставі яскравих геополітичних та цивілізаційних перетворень. Громадянство поступово втрачає свою насамперед територіальну «прив'язку» до конкретної держави, реальний та ефективний політико-правовий зв'язок між державою та особою перестає бути таким у зв'язку із глобалізацією [7]. Натомість першу роль починає відігравати фінансово-правовий зв'язок між фізичною особою та державою. Місце постійного перебування особи є єдиним фактором, що вказує на поширення на цю особу суверенітету держави. У зв'язку 3 цим фінансово-правовий зв'язок можна простежити як через принцип резидентства, так і через принцип територіальності походження доходів - це дві основи для поширення податкової юрисдикції держави.

Сучасна інтерпретація правової категорії «суверенітет» вказує на те, що це - багаторівневе публічно-правове явище. Науковець Н.В. Ткаченко, зробивши аналіз рівнів суверенітету, зазначає, що однією з невід'ємних складових частин суверенітету держави є іï економічний суверенітет, який є здатністю до самодостатнього стійкого та безпечного відтворення національної економіки як соціально-економічної цілісності. Своєю чергою невід'ємним елементом економічного суверенітету держави $є$ фінансовий суверенітет, який означає право держави вводити на власній території податки та мита, забороняти або заохочувати ввезення чи вивезення капіталів, емітувати гроші, брати позики тощо. У складі фінансового суверенітету держави окремі вчені [8] виділяють фіскальний суверенітет, який означає повноваження держави здійснювати правове регулювання не лише податкових, але і тих правовідносин, що виникають у зв'язку зі встановленням інших видів бюджетних доходів. Стосовно цього Н.Ю. Пришва зазначає, що на характеристику доходів як публічних не впливає чинник їх джерела формування. Це можуть бути і податки, і добровільні надходження, і плата за публічні послуги (адміністративні), що надаються суб́'єктами публічного права. Проте існують види доходів, які можуть надходити тільки до публічного фонду [9]. Ідеться про обов'язкові платежі, які є основним джерелом формування будьякого публічного фонду. Інші дослідники [10] переконані, що фінансовий суверенітет держави грунтується на валютному, інвестиційному та банківському суверенітетах [11]. Тобто сучасні наукові позиції на внутрішню будову суверенітету держави, в частині відтворювальних майнових процесів, відображають наступну класифікацію: державний суверенітет - економічний суверенітет фінансовий суверенітет - фіскальний суверенітет. Одночасно з цим останній із перелічених видів суверенітетів розглядають як самостійний вид або 3 нього виділяють податковий суверенітет, до якого відносять мобілізацію не всіх видів грошових ресурсів до централізованих фондів коштів, а лише платежі податкового характеру. Стосовно цього науковці Д.М. Осика та В.М. Дворецький зазначають, що фіскальний суверенітет - поняття більш широке, ніж податковий, позаяк перелік встановлених державою публічних платежів, що надходять до публічних фондів коштів, досить широкий i не обмежується лише податками [12].

Однією з ознак сучасної держави поряд 3 територією, населенням та публічною владою є здатність породжувати податкові правовідносини. Податковий суверенітет держави - це визнане міжнародним співтовариством виключне право держави на породження податкових правовідносин на своїй території, що поширюються на осіб, які пов'язані $з$ державою фінансово-правовим зв'язком. Адже сучасна фінансова система держави грунтується не на надходженнях до публічних фондів коштів від реалізації сировини або доходів від доменів чи регалій, а на оподаткуванні: всі державні інститути забезпечуються фінансовими ресурсами переважно $з$ податкових надходжень. Таким чином, можна вести мову, що податковий суверенітет - це одна з головних ознак сучасної держави. 
Форми реалізації податкового суверенітету різні і включають, зокрема, такі складники: встановлення податків, визначення кола платників податків, а також усіх обов'язкових елементів оподаткування (об'єкта оподаткування, податкової бази, податкового періоду, податкової ставки, порядку обчислення податку, порядку і термінів сплати); встановлення способів забезпечення виконання обов'язку зі сплати податків і відповідальність за порушення встановленого порядку; здійснення державою постійного податкового контролю за дотриманням встановленого ним порядку взаємодія з іншими державами з питань оподаткування, в тому числі укладення відповідних угод [12]. Держава самостійно визначає межі поширення своєї публічної влади в сфері оподаткування. Але варто звернути увагу, що реалізація податкового суверенітету в міжнародних відносинах обмежена на двох рівнях: міжнародному - міжнародним публічним правом; національному - податковою юрисдикцією. Так, згідно з міжнародним правом адміністрування державою податків $є$ нелегітимним, якщо немає суттєвого зв’язку суб'єкта з державою. Тобто суб'єкт оподаткування має бути пов'язаний 3 державою фінансово-правовим зв'язком, який здебільшого грунтується на принципі резидентства.

Стосовно принципу резидентства варто звернути увагу на міждержавні угоди щодо уникнення подвійного оподаткування. У наукових роботах є точка зору, що, укладаючи двосторонні податкові угоди, держави добровільно обмежують застосування свого національного права, що потенційно веде до скорочення надходжень до бюджетів, але у цьому разі найбільш обгрунтованою видається позиція Д.М. Осики та В.М. Дворецького, відповідно до якої угоди про уникнення подвійного оподаткування не встановлюють ані податки, ані відповідальність за невиконання податкових зобов'язань. Тобто суверенітет держави в податковій сфері так і залишається непорушним, оскільки суверенітет є необхідною умовою існування самої держави [12], за наявності якого держави, власне, і мають можливість укладати угоди про уникнення подвійного оподаткування.

Діяльність держав на міжнародній арені потребує окремої уваги в контексті цього дослідження. У сучасному світі податковий суверенітет держави може бути обмежений поширенням наддержавної податкової юрисдикції, яскравим прикладом цьому є податкові правовідносини в Свропейському Союзі (надалі - СС). Актуальною проблематикою є оподаткування в $\mathrm{CC}$, де держави-члени зберігають суверенітет, особливо в сфері прямого оподаткування. Повноваження держав щодо оподаткування, як правило, вступають у конфлікт 3 цілями міждержавних об'єднань, особливо з основними економічними свободами. Ці свободи закріплені як в установчих договорах міжнародних організацій і деталізуючих їх положеннях, актах «жорсткого права» (наприклад, директивах (C), так і в актах «м'якого права». Аналогічний вплив також здійснюють двосторонні податкові угоди щодо уникнення подвійного оподаткування, хоча ці угоди можуть розглядатися і як прояв податкового суверенітету [13]. Але податковий суверенітет держав-членів обмежений правом СС. Хоча пряме оподаткування не підпадає під компетенцію Союзу, повноваження держав-членів мають у будь-якому разі реалізовуватися відповідно до наднаціонального податкового права. Це закріплено в рішенні Суду Свропейського Союзу у справі від 14.02.1995 р. № C-279/93 "Finanzamt K ln-Altstadt v Roland Schumacker" [14]. Це твердження, очевидно, відображає конфлікт двох рівнів. Судова практика неодноразово вказувала на пріоритет права $\mathrm{CC}$ над національним правом. Норми Договору про функціонування Європейського Союзу $є$ нормами прямої дії, отже, будь-яка національна норма, що їм суперечить, визначається нечинною [13].

\section{Висновки}

Досить тривалий час правова категорія «суверенітет», залишалась сталою у своєму змістовому визначенні. Але з переходом від сировинної моделі економіки до економіки доданої вартості на науковому рівні було виділено категорію «економічний суверенітет», подальший розвиток якої призвів до обгрунтування таких правових категорій, як фінансовий суверенітет та фіскальний суверенітет. Публічні фонди коштів стрімко почали наповнюватись за рахунок обов'язкових платежів, що сплачували фізичні та юридичні особи у зв'язку зі своєю економічною активністю. На цей час наукова спільнота 3 фіскального суверенітету виділяє податковий.

Будь-яка сучасна держава існує з єдиною метою - задоволення публічного інтересу, який може бути реалізований лише за наявності відповідного фінансування. Публічні фонди коштів наповнюються через перерозподіл валового національного доходу за допомогою обов'язкових платежів, що встановлюються державою у формі податків та інших неподаткових платежів. Власне, можливість встановлення та адміністрування податків і $є$ податковим суверенітетом 
держави. Іншими словами, сучасна держава $\epsilon$ легітимним публічно-правовим утворенням лише у разі фактичної реалізації своїх основних функцій - внутрішніх та зовнішніх, які можуть бути виконані лише за наявності грошових коштів. Цей теоретичний висновок можна обгрунтувати на емпіричному рівні за допомогою ретроспективного аналізу проголошення суверенітету України. Так, одночасно з проголошенням політичного суверенітету Декларація про Державний суверенітет [15] передбачала створення самостійної фінансової системи, на реалізацію чого було ухвалено Закон України «Про бюджетну систему Української РСР» від 05.12.1990 № 512-XII [16] та Закон Української РСР «Про систему оподаткування» від 25.06.1991 р. № 1251-ХІІ [17]. У результаті поширення податкового суверенітету та фактичної реалізації податкової юрисдикції, наповнивши публічні фонди коштів, було проголошено незалежність України [18].

У сучасному світі податковий суверенітет держави може бути обмежений лише наднаціональним, яскравим прикладом цьому є податкові правовідносини в Свропейському Союзі.

3 огляду на важливість проблематики фінансової безпеки держави та ї̈ утвердження на міжнародній арені, правова категорія «податковий суверенітет» потребує легального закріплення на законодавчому рівні.

\section{Список використаних джерел:}

1. Сюзюмов М.Я. Суверенітет, податок i земельна рента у Візантії. Антична старовина $i$ середні віки. 1973. Вип. 9 (1973). С. 58.

2. Гапотій В.Д. Теоретичні та практичні аспекти суверенітету народу, нації та держави : автореф. дис. на здобуття наук. ступеня канд. юрид. наук : спец. 12.00.01. Міністерство внутрішніх справ України. 2005. С. 8-9.

3. Романова А.С. Людина у природно-правовому просторі: інтелігібельний і сенсибельний виміри : дисертація на здобуття наук. ступеня доктора. юр. наук : 12.00.12. Львів. 2016. С. 99-100.

4. Коваль О.Я. Легітимність державної влади: співвідношення правових і моральних аспектів реалізації : дисертація на здобуття наук. ступеня канд. юр. наук : 12.00.01. Львів. 2017. С. 50-51.

5. Коваль І.М. Метаантропологія менталітету: правовий вимір : дисертація на здобуття наук. ступеня кандидата. юр. наук : 12.00 .12 . Львів. 2017. С. 54.

6. Гидирим В.А. Основы международного корпоративного налогообложения. 2016 ISBN 978-5-9908572-2-3. C. 55-56.
7. Софінська І.Д. Філософсько-правова доктрина громадянства : дисертація на здобуття наук. ступеня док. юр. наук : 12.00.12. Львів. 2019. C. 81,104 .

8. Орлов М.Ю. Налог как форма разумного ограничения фискального суверенитета государства. Финансовое право. 2006. № 2. С. 18-23.

9. Пришва Н.Ю. Публічні доходи як фінансово-правова категорія. Проблеми законності. 2010. Вип. 111. С. 146-153. URL: http://nbuv. gov.ua/UJRN/Pz_2010_111_20 (дата звернення: 31.03.2020).

10. Юрьева Н.П. Национальный экономический суверенитет в условиях глобализации : автореф. дис. канд. экон. наук : 08.00.01. Москва. 2009. 33 c.

11. Ткаченко Н.В. Фінансова політика як інструмент реалізації економічного суверенітету держави. Економічний аналіз. № 20, 2015. C. 203-209. URL: http://www.irbis-nbuv.gov.ua/ cgi-bin/irbis_nbuv/cgiirbis_64.exe?C21COM=2 $\& \mathrm{I} 21 \mathrm{DBN}=\overline{\mathrm{U}} \mathrm{R} \mathrm{R} \& \mathrm{P} 21 \mathrm{DB} \overline{\mathrm{N}}=\mathrm{UJRN} \& \mathrm{IMAGE}$ FILE DOWNLOAD $=1 \&$ Image file_name $=P D F /$ ecan $2015 \quad 20$ 29.pdf (дата звернення: 31.03.2020).

12. Осика Д.М., Дворецький В.М. Поняття і межі фіскального (податкового) суверенітету держави. Податки і оподаткування. 2019. № 3. С. 1-8. DOI: 10.7256 / 2454-065X.2019.3.29138 URL: https://nbpublish.com/library_read_articlephp?id=29138(дата звернення: 31.03.2020)

13. Пономарьова К.А. Налоговый суверенитет в условиях взаимодействия интеграционного и национального налогового права. Вестник ВГУ. Серия: Право. 2016. С. 248. URL: http://www. vestnik.vsu.ru/pdf/pravo/2016/03/2016-03-24.pdf (дата звернення: 31.03.2020).

14. Рішення Суду Європейського Союзу у справі від 14.02.1995 р. № C-279/93 "Finanzamt K ln-Altstadt v Roland Schumacker". URL: https://eur-lex.europa.eu/legal-content/GA/ TXT/?uri=CELEX:61993CJ0279 (дата звернення: 31.03.2020).

15. Декларація про Державний суверенітет. Відомості Верховної Ради уРСР (ВВР), 1990 № 31, ст. 429. URL: https://zakon.rada.gov.ua/ laws/show/55-12 (дата звернення: 31.03.2020).

16. Про бюджетну систему Української PCP : Закон України від 05.12.1990 № 512-XII Відом. Верхов. Ради УРСР. 1991. № 1. Ст. 1. (дата звернення: 31.03.2020).

17. Закон Української РСР «Про систему оподаткування» від 25.06.1991, № 1251-XII. URL: http://zakon5.rada.gov.ua/laws/show/1251-12/ ed19910625 (дата звернення: 31.03.2020).

18. Про проголошення незалежності України : Постанова Верховної Ради України; Акт від 24.08.1991 № 1427-XII. База даних «Законодавство Украӥни» / Верховна Рада Украӥни. URL: https://zakon.rada.gov.ua/go/1427-12 (дата звернення: 31.03.2020). 
The scientific problems of the concept of tax sovereignty of a state are addressed in the article. In this article the author researches the viewes of scientists on political sovereignty and makes a retrospective analysis of scientific positions on this legal category. The author accentuates the fact that society is organized in the form of a state according to specific characteristics and certain common ideals that distinguishes it among other communities. The people is the only source of power in the modern rule of law - the population of a state, which exercises power directly and through state and local governments. The sovereignty of the state is the supremacy of the public authority in the formulation and implementation of domestic and foreign policy throughout the territory covered by such authority. The article concludes with the different types of sovereignty of the modern state. Modern scientific positions on the internal structure of the sovereignty of the state, in terms of reproductive property processes, reflect the following classification: state sovereignty - economic sovereignty - financial sovereignty - fiscal sovereignty - tax sovereignty. The content component of this category is also considered. The financial system of the state is not based on revenues to the public funds from the sales of resources; the financial system is based on taxation - all state institutions are provided with financial resources, mostly from tax revenues. Thus, tax sovereignty is one of the main features of the modern state. The definition of the legal category of "tax sovereignty" is provided as the internationally recognized absolute right of the state to generate tax relations on its territory, and it includes individuals connected with the state by financial relations. The author examines scientific positions of the exclusive right of a state to establish tax relationships. Types and levels of a state's tax jurisdiction are analysed. In each case, the residency status of the person, from whom the state mobilized funds to the budget, is determined by legislative act only within the relationships that this act regulates. The author offers the legislative approaches to determining the legal status of those providing the main function of financial relationships - mobilization of funds to the budgets of Ukraine.

Key words: public finance, tax sovereignty, tax jurisdiction, financial nexus, public authority. 